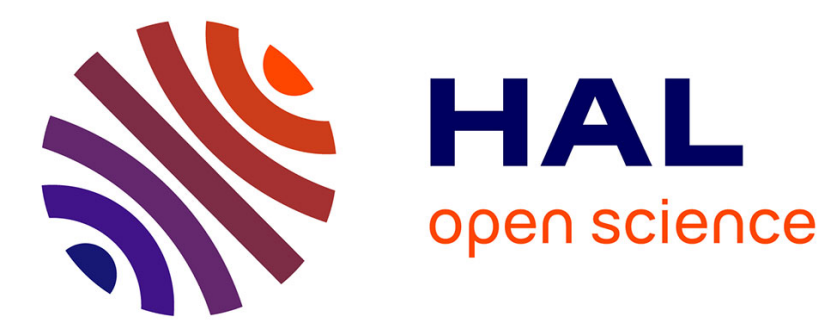

\title{
Post-transcriptional regulation in Xenopus embryos: role and targets of EDEN-BP.
}

Howard Beverley Osborne, Carole Gautier-Courteille, Antoine Graindorge, Carine Barreau, Yann Audic, Raphaël Thuret, Nicolas Pollet, Luc Paillard

\section{- To cite this version:}

Howard Beverley Osborne, Carole Gautier-Courteille, Antoine Graindorge, Carine Barreau, Yann Audic, et al.. Post-transcriptional regulation in Xenopus embryos: role and targets of EDEN-BP.. Biochemical Society Transactions, 2005, 33 (Pt 6), pp.1541-3. 10.1042/BST20051541 . inserm00292938

\section{HAL Id: inserm-00292938 https://www.hal.inserm.fr/inserm-00292938}

Submitted on 29 Jul 2008

HAL is a multi-disciplinary open access archive for the deposit and dissemination of scientific research documents, whether they are published or not. The documents may come from teaching and research institutions in France or abroad, or from public or private research centers.
L'archive ouverte pluridisciplinaire HAL, est destinée au dépôt et à la diffusion de documents scientifiques de niveau recherche, publiés ou non, émanant des établissements d'enseignement et de recherche français ou étrangers, des laboratoires publics ou privés. 
Post-transcriptional Regulation in Xenopus embryos: Role and targets of EDEN-BP.

H.B.Osborne, C. Gautier-Courteille, A. Graindorge, C. Barreau, Y. Audic, R Thuret*, N. Pollet*, L.Paillard.

CNRS UMR 6061, IFR 140, Université de Rennes 1, Rennes, France. * CNRS UMR 8080, Université Paris Sud, Orsay, France.

Keywords: maternal mRNA, deadenylation, translation, Segmentation, Notch signalling, $\mathrm{XSu}(\mathrm{H})$.

Abbreviations: EDEN, Embryo Deadenylation Element; EDEN-BP, EDEN-binding protein; 3' UTR, 3' untranslated region; PSM, pre-somitic mesoderm; XSu(H), Xenopus Suppressor of Hairless

Corresponding author H.B.Osborne e-mail: beverley.osborne@univ-rennes1.fr. Postal adresse: H.B.Osborne, UMR 6061, Faculté de Médecine, Université de Rennes 1, 2 avenue du Professeur Léon Bernard, CS 34317, 34043 Rennes cedex, France.

Word count: 1541 with references; 1348 without references; 11 references; 1 figure. 


\begin{abstract}
.
EDEN (Embryo Deadenylation ElemeNt) dependent deadenylation is a regulatory process that was initially identified in Xenopus laevis early embryos and was subsequently shown to exist in Drosophila oocytes. Recent data showed that this regulatory process is required for somitic segmentation in Xenopus. Inactivation of EDEN- binding protein (EDEN-BP) causes severe segmentation defects and the expression of segmentation markers in the Notch signalling pathway are disrupted. We showed that the mRNA encoding Xenopus Suppressor of Hairless, a protein central to the Notch pathway, is regulated by EDEN-BP. Our data also indicate that other segmentation RNAs are targets for EDEN-BP. To identify new EDEN-BP targets a micro-array analysis has been undertaken.
\end{abstract}

\title{
Introduction
}

The post-transcriptional regulation of gene expression within the cytoplasm of cells has numerous facets such as translational activation or silencing and localisation. Control of gene expression at this level is particularly important in oocytes and early embryos. Indeed, in all species studied to date transcription is essentially silent during the completion of meiosis (maturation) and the first mitotic divisions. This situation has both high-lighted the importance of post-transcriptional controls and enabled the study of these mechanisms. In Xenopus, mouse and probably many other species one of the major mechanisms that activates or represses the translation of maternally inherited mRNAs is via a control of the poly(A) tail length. Two sequence elements required for post-fertilisation deadenylation (poly(A) tail shortening) have been identified; the Embryo Deadenylation ElemeNt (EDEN) [1] and the AUUUA containing AU rich elements [2] both localised within the 3' untranslated region (3'UTR) of affected mRNAs. It is necessary to mention that contrary to the general situation in somatic cells, in early embryos deadenylated mRNAs are not immediately degraded and the coupling between mRNA deadenylation and degradation is only restored after the resumption of transcriptional activity at the 12 th mitotic cell cycle [2-4]. This may have developmental importance as the "protection" of deadenylated mRNAs implies that maternally inherited poly(A) $)^{-}$mRNAs whose translation is activated after the initial mitotic cycles are also protected. We will concentrate here on the EDEN-dependent pathway.

\section{The EDEN sequence.}

Mapping for regulatory sequences in the 3'UTR of mRNAs deadenylated in embryos has shown that functional EDENs are situated within U/purine rich regions (reviewed in [5]). 
Indeed, a synthetic motif composed of at least 6 contiguous (UGUA) motifs can confer postfertilization deadenylation on a reporter mRNA [6]. However, comparison of the EDENcontaining regions has not identified any particularity sequence motif, so, to date, EDENs can not be efficiently identified using in silico based methods. To complicate the picture, two auxiliary sequence elements that assist the EDEN mechanism have been identified, an AUU repetition [6] and a single AUUUA motif [7].

In oocytes and early embryos deadenylation is strongly correlated with translational repression. This functional aspect of the EDEN is evolutionary conserved as the translation of a reporter mRNA containing a synthetic EDEN is repressed in the ovaries of transgenic Drosophila [8] whereas the stability and localisation of the mRNA were normal. This regulatory mechanism is also probably conserved in humans as the instability element in the 3'UTR of human c-jun mRNA is U/purine rich and behaves like an EDEN when present within the 3'UTR of a reporter mRNA injected into Xenopus embryos [9].

\section{EDEN-BP, the associated factor.}

Most regulatory RNA motifs function as target sites for sequence specific RNAbinding proteins that are, directly or indirectly, the functional actors in the regulatory processes. The protein binding to the EDEN, EDEN-binding protein (EDEN-BP) is a $54 \mathrm{kDa}$ protein containing 3 RNA recognition motifs, two in the $\mathrm{N}$-terminal region and one in the $\mathrm{C}$ terminal part [1]. It is required for the EDEN-dependent deadenylation process. The particular arrangement of the three RNA recognition motifs is characteristic of a large super-family of proteins including the drosophila Elav and bruno proteins and the mammalian Hu proteins. At the amino acid level EDEN-BP has $88 \%$ identity with the human protein CUG-binding protein 1 and this protein can functionally replace EDEN-BP in a Xenopus extract [10].

\section{Biological Roles.}

With the intention of identifying a biological role for EDEN-dependent deadenylation we developed a protocol to inactivate EDEN-BP in Xenopus embryos using either antisense morpholinos oligonucleotides or neutralizing antibodies [11]. The most important phenotype observed was a disruption of somitic segmentation (see Figure). Somites are prospective muscle and bones. They are made of a series of similar and successive units by a process termed segmentation. In EDEN-BP inhibited embryos, loss of segmentation is associated with a modified expression of a number of markers in the presomitic mesoderm (PSM), where segmentation takes place and which comprises the tail bud domain and presumptive somites 
(see Figure). Using a candidate gene approach we found one mRNA that is posttranscriptionally regulated by EDEN-BP in the PSM. This mRNA encodes $\mathrm{XSu}(\mathrm{H})$ (Xenopus Suppressor of Hairless) a protein central in the Notch signalling pathway. EDEN-BP knockdown reduced the efficiency of deadenylation targeted by the 3'UTR of $\mathrm{XSu}(\mathrm{H})$ and caused an over-expression of $\mathrm{XSu}(\mathrm{H})$ mRNA. Also over-expressing $\mathrm{XSu}(\mathrm{H})$ caused segmentation defects. $\mathrm{XSu}(\mathrm{H})$ is required for the transcriptional activation of Notch target genes and our data indicates that its over-expression disrupts the correct regulation of these genes.

\section{New EDEN-BP targets.}

If $\mathrm{XSu}(\mathrm{H})$ was the only mRNA targeted by EDEN-BP in the PSM then a morpholino induced down regulation of this gene product should rescue the phenotype caused by EDENBP inactivation. This was not observed which implies that other mRNAs expressed in the PSM are also targets for this regulatory pathway [11]. As a first step in the identification of such mRNAs a DNA micro-array screen was initiated to analyse specific changes in the adenylation status of Xenopus tropicalis maternal mRNAs. Of the 3000 gene products tested about 500 showed detectable adenylation changes and could be classified into 7 characteristic behaviours (A. Graindorge, Y. Audic, R Thuret, N. Pollet, H.B.Osborne unpublished data).

\section{Perspectives.}

Future work on the molecular characterisation of the EDEN-dependent deadenylation mechanism will involve the identification of interacting proteins and a characterisation of their functional roles coupled with a wide scale identification of the mRNA targets and a description of their expression patterns in the embryos and adult tissues.

Acknowledgements: The work described in this review was supported by grants from ARC (HBO $n^{\circ}$ 9529; LP $n^{\circ} 4791$ and YA post-doctoral fellowship), the French Ministry of Research BCMS ACI n 314, the CNRS "Xénopuces“" project (NP n 02N65/0029) and the LRCC (Bretagne).

\section{References:}

1 Paillard, L., Omilli, F., Legagneux, V., Bassez, T., Maniey, D. and Osborne, H. B. (1998) EMBO J. 17, 278-287

2 Voeltz, G. K. and Steitz, J. A. (1998) Mol Cell Biol 18, 7537-45 
3 Duval, C., Bouvet, P., Omilli, F., Roghi, C., Dorel, C., LeGuellec, R., Paris, J. and Osborne, H. B. (1990) Mol. Cell. Biol. 10, 4123-4129

4 Audic, Y., Omilli, F. and Osborne, H. B. (1997) Mol. Cell. Biol. 17, 209-218

5 Paillard, L. and Osborne, H. B. (2003) Biol Cell 95, 211-9

6 Audic, Y., Omilli, F. and Osborne, H. B. (1998) Mol Cell Biol 18, 6879-84

7 Ueno, S. and Sagata, N. (2002) Dev Biol 250, 156-67

8 Ezzeddine, N., Paillard, L., Capri, M., Maniey, D., Bassez, T., Aït-Ahmed, O. and Osborne, B. (2002) Proc. Natl. Acad. Sci. U. S. A. 99, 257- 262

9 Paillard, L., Legagneux, V., Maniey, D. and Osborne, H. B. (2002) J Biol Chem 277, $3232-5$

10 Paillard, L., Legagneux, V. and Osborne, H. (2003) Biol Cell 95, 107-13

11 Gautier-Courteille, C., Le Clainche, C., Barreau, C., Audic, Y., Graindorge, A., Maniey, D., Osborne, H. B. and Paillard, L. (2004) Development 131, 6107-17 
Legend to figure:

Figure In vivo inhibition of EDEN-BP causes segmentation defects.

Left panel: Inhibiting the translation of EDEN-BP mRNA by oligonucleotide morpholinos (Mo) causes an accumulation of $\mathrm{XSu}(\mathrm{H})$ mRNA. The co-injection of a mRNA encoding EDEN-BP (modified to escape down-regulation by the Mo) prevents $\mathrm{XSu}(\mathrm{H})$ overexpression. NI not-injected. Middle panel: $\mathrm{XSu}(\mathrm{H})$ is a central element in Notch signalling and the mRNAs encoding many proteins implicated in this pathway are expressed in a stripped pattern (panels A and C). Inhibiting EDEN-BP expression by Mo causes important modifications in the expression patterns of at least two of the mRNAs encoding Notch signalling proteins, ESR 5 and X Delta 2 (panels B and D). TBD, tail bud domain, S1 to S4 correspond to four presumptive somites. Right panel: Inhibiting EDEN-BP causes segmentation defects. The bottom half of the embryos is derived from one cell of a 2 cell embryo injected with anti EDEN-BP antibodies. The upper half, derived from the noninjected cell, serves as a control. (n) notochord; (s) somite, Scale bar 50 $\mu \mathrm{m}$. (Modified from Gautier et al., 2004, Reproduced with permission from the Company of Biologist). 


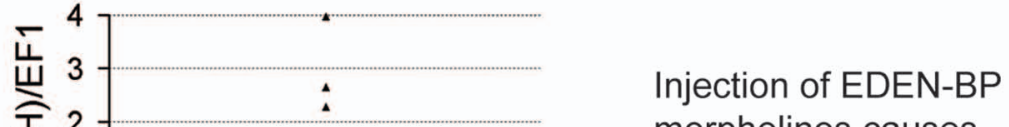

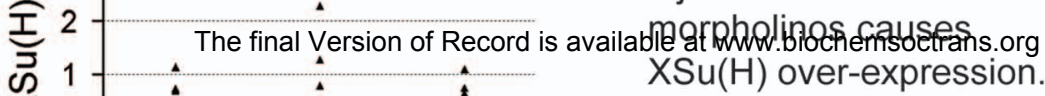
(ี 0

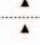

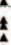

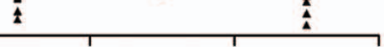

$\mathrm{Ni}$

Mo

\section{Mo + \\ EDEN-BP \\ RNA}
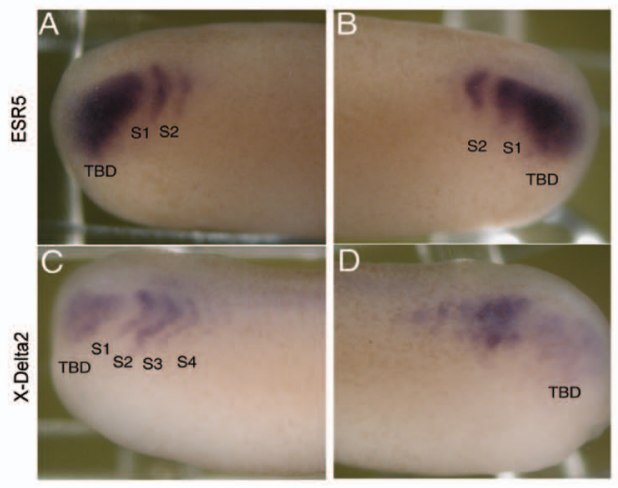

\section{$\mathrm{XSu}(\mathrm{H})$ over-expression.}

Inhibition of EDEN-BP affects Notch signalling as shown by modified ESR5 and XDelta 2 expression paterns.

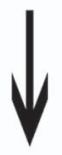

This leads to segmentation defects 